\title{
Mejorando la gestión editorial
}

Nuestra revista Biological Research es definitivamente una de las publicaciones científicas del área de la Biología y de origen latinoamericano con mayor impacto a nivel internacional. Su Factor de Impacto ISI, si bien menor a lo que llegó en el año 2004 (2.173), continúa siendo significativo (actualmente 1.057). Con la intención de mejorar la labor editorial de la revista para volver a obtener mejores cifras de Factores de Impacto, e incluso superarlas, la Mesa Directiva de la Sociedad de Biología de Chile ha optado por seguir introduciendo cambios en el manejo editorial de nuestra publicación.

Las medidas tomadas son las siguientes:

- A corto plazo, se optó por realizar cambios en el equipo directivo del Comité Editorial. Entre ellos, se reemplazó al Editor Jefe, Dr. Jorge Garrido, quien permaneció en el cargo durante dos años, y se nombró como Editor Jefe Subrogante al suscrito (en su calidad de Presidente de la Sociedad de Biología de Chile). Como Editor Asociado se incorporó al Dr. Christian González, de la Facultad de Ciencias de la Universidad de Chile, quien con el otro Editor Asociado, Dr. Ricardo Moreno, y el nuevo Editor Jefe, han constituido un buen grupo de trabajo que ya ha mejorado significativamente el manejo de los artículos enviados a publicación en Biological Research.

- A mediano plazo se está implementando un manejo editorial mediante una plataforma web. Para ello, la Sociedad de Biología de Chile concursó y, posteriormente, logró obtener financiamiento a través de un proyecto del Concurso Fondo de Publicación de Revistas Científicas de CONICYT, titulado: "Desarrollo y puesta en marcha de una plataforma electrónica para la gestión editorial de Biological Research" (Proyecto No 32). En la actualidad, avances importantes ya se han realizado en la ejecución del proyecto, de modo que estimamos que en el próximo año 2009 la plataforma web ya debería estar en pleno funcionamiento.

- A largo plazo, la Sociedad de Biología de Chile intentará situar a su revista Biological Research en una posición cada vez mejor en el amplio espectro de las ediciones científicas internacionales indexadas del área biológica.

El éxito de estas iniciativas tendientes a optimizar la labor editorial de Biological Research, para lograr mejorar su impacto, dependerá indudablemente de la calidad de los artículos científicos que publique. Y ello será consecuencia de que los investigadores chilenos y extranjeros escojan prioritariamente esta revista para publicar sus resultados. Por tanto, invitamos a todos los investigadores a publicar sus resultados en Biological Research

DR. MAnUel J. SANTOS

Presidente de la Sociedad de Biología de Chile 2007-2008 Editor Jefe $(S)$ de Biological Research 


\section{Improving the editorial management}

Our Biological Research Journal is definitively one of the Latin American scientific publications in the area of biology with the highest scientific impact at the international level. Its ISI Impact factor, although somewhat lower than in previous years (2.173 in 2004), is still high (1.057 in 2008) by Latin American standards. In order to improve the Journal's editorial management and thus reach higher ISI Impact Factors, the Board of the Sociedad de Biología de Chile has decided to introduce several editorial changes:

- Short term measures: The editor in chief, Dr. Jorge Garrido, who was the editor for two years, was replaced by Dr. Manuel J. Santos, the President of the Sociedad de Biología de Chile. As an Associate Editor, Dr. Christian González, from the Faculty of Sciences of the Universidad de Chile, was incorporated to the Editorial Board. The new team formed by the new Editor and the Associate Editors (Dr. Christian Gonzàlez, and Dr. Ricardo Moreno) has been working hard on coordination to improve the editorial management of manuscripts submitted to Biological Research.

- Middle term measures: The Editorial office is setting up a new web platform to receive and manage the manuscripts submitted to Biological Research. The Sociedad de Biología de Chile applied and successfully obtained funds from CONICYT to carry out the Project "Development and Setting Up of an Electronic Platform for the Editorial Management of Biological Research" (Project $N^{\circ} 32$ ). At present, important advances have been made concerning this Project. We hope that this web platform will be available in 2009 for all Biological Research manuscript management.

- Long term measures: The Sociedad de Biología de Chile will try to place its Journal Biological Research in a better position in the wide spectrum of indexed scientific latinoamerican journals in the biological area.

The success of these measures, designed to improve the Editorial management of Biological Research, will undoubtedly depend on the scientific quality of the published articles. This in turn will depend on the decision made by Chilean and foreign investigators to send their articles describing their novel scientific results to this journal. We therefore invite all investigators to publish their results in Biological Research.

DR. MANUEL J. SANTOS

President of the Sociedad de Biología de Chile 2007-2008

Editor-in Chief (S), Biological Research

July of 2008 